\title{
Natural Ice Nucleus Measurement under High Supersaturation
}

\author{
By Hakaru Mizuno \\ Meteorological Research Institute, Tsukuba, Ibaraki 305, Japan \\ and \\ Norihiko Fukuta \\ Department of Meteorology, University of Utah, Salt Lake City, Utah 84112, U.S.A. \\ (Manuscript received 4 July 1995, in revised form 12 October 1995)
}

\begin{abstract}
To understand ice nucleation under high supersaturation in clouds, measurements of natural ice nuclei for supersaturation with respect to water $\left(S_{w}\right)$ up to $10 \%$ from -20 to $-24^{\circ} \mathrm{C}$ were carried out using a horizontal gradient, continuous flow, ice thermal diffusion chamber after solving the spurious count problem due to ice crystal protrusion on the bottom plate with the addition of a small amount of ethylene glycol. The measurements were made with continental air masses in early summer of 1993 at Salt Lake City, Utah in the United States of America.

The measured ice nucleus concentration under the condition of $-20^{\circ} \mathrm{C}$ and $S_{w} 5 \%$ showed a daily variation. The ice nucleus concentration changed from about $10 l^{-1}$ in a warm air mass to about $1 l^{-1}$ in a cold air mass, respectively, before and after the passage of a cold front in the synoptic scale. It was inferred that the instability of the warm air mass helps raise the particulates from or near the ground to increase the ice nucleus concentration. In order to pick out the supersaturation dependence at the various temperatures, the ratio of the ice nucleus concentration $(N)$ to that at water saturation $\left(N_{o}\right)$ was estimated. On average, $S_{w}$ increases of 5 and $10 \%$ raised the $N / N_{o}$ ratio by as much as a factor of two or more, respectively. It was found that a general relationship exists between $N / N_{o}$ and $S_{w}$, and the slope further steepens above water saturation.
\end{abstract}

\section{Introduction}

It is well known that ice-phase cloud microphysics plays an important role not only in the mechanisms of precipitation formation but also in the earth's radiation balance. Most precipitation in middle and high latitudes comes from cold clouds which contain ice particles. Ice clouds control reflection of solar radiation and interact with infrared radiation emitted by the earth's surface and lower clouds. The detailed information on ice phase processes is thus needed to understand precipitation mechanisms and radiative properties of cold clouds.

One of the most important processes of ice-phase cloud microphysics is the generation of ice crystals. Ice crystals are produced primarily by ice nucleation processes, but it has been known that there are some clouds which contain high ice particle concentrations (100 $l^{-1}$ or more) several orders of magnitude greater than that of the ice nucleus (Hobbs, 1969

(C) 1995 , Meteorological Society of Japan and 1974; Pruppacher and Klett, 1980; Mossop, 1985; Hobbs and Rangno, 1985).

Several mechanisms are proposed to account for the high concentration of ice particles in some clouds. Hallett and Mossop (1974) and Mossop and Hallett (1974) found a multiplication process that operates at temperatures around $-5^{\circ} \mathrm{C}$ for ice particles with large fall velocities in supercooled clouds containing relatively large droplets. It has been shown that a crystal-crystal collision generates secondary ice particles (Hobbs and Farber, 1972; Vardiman, 1978; Griggs and Choularton, 1986). A contact ice nucleation mechanism under the evaporating condition of clouds, where the phoretic force on the nucleus particles is toward the droplets, was also cited as a possible mechanism for ice enhancement (Young, 1974). However, these mechanisms are not considered to be sufficient to account for the high ice particle concentration observed in some clouds (Mossop, 1985; Hobbs and Rangno, 1985 and 1990; Takahashi, 1993). 
Recently, Hobbs and Rangno (1990) and Rangno and Hobbs (1991) suggested from field observations that a large number of ice particles might be nucleated under high supersaturation with respect to water. High supersaturation up to about $10 \%$ is expected in clouds by Young (1974), Hall (1980), DeMott et al. (1992) and Fukuta (1993). Therefore, a laboratory experiment of ice nucleus activation in cloud-forming air under high supersaturation with respect to water is crucially needed to check this hypothesis (Rangno and Hobbs, 1991; Hobbs, 1993).

The purpose of this study is, therefore, to determine the dependency of the activity of natural ice nuclei on supersaturation for air masses of different origin.

\section{Experimental technique}

All measurements were carried out in June 1993 at Salt Lake City (N $40^{\circ} 47^{\prime}$, W $111^{\circ} 57^{\prime}$ ), Utah in the United States of America. Utah is located in the zone of prevailing westerly winds where polar and tropical air masses pass over and frontal activity dominates. In addition to its latitudinal position, the continental location is also a dominant factor affecting Utah's weather (Stevens et al., 1983; Brough et al., 1987). The Cascades and the Sierras in the west and the Rockies in the east act as barriers to low-level moisture and place Utah in a rather dry area. The measurements are thus considered to be representative of the mid-latitude continental area.

\subsection{Instrumentation}

A horizontal gradient, continuous flow, ice thermal diffusion chamber (Tomlinson and Fukuta, 1985) was used to measure ice nucleus concentration. The chamber can provide an accurate condition of temperature and supersaturation in sample air by controlling temperatures of the top and bottom plates which are coated with smooth ice. Sample air is sandwiched in between clean filtered air to make use of the nearly constant zone of supersaturation. The chamber overcomes problems encountered in other methods, such as volume effect due to growth of ice particles, hygroscopic particles and substrate effect on filters in the filter method and transient supersaturations during the sample air introduction in the mixing chamber. It is described in detail in Tomlinson and Fukuta (1985).

Prior to the ice nucleus measurement, we improved this chamber to achieve high supersaturation with respect to water up to about $10 \%$ and to overcome spurious ice nucleus counts generated by the ice crystal protrusion from the bottom plate.

Figure 1 shows the relationship between supersaturation with respect to water $\left(S_{w}\right)$ and temperature $(T)$ achieved in the chamber by controlling the bottom temperature $\left(T_{b t m}\right)$ and the top plate temperature $\left(T_{t o p}\right)$. Since the steady-state profiles of temperature and vapor pressure between the plates are linear, temperature $(T)$ and the saturation ratio with respect to water $\left(S_{w}+1\right)$ at the point with a distance $x$ from the bottom plate may be obtained as,

$$
T=T_{b t m}+x\left(T_{t o p}-T_{b t m}\right) / d,
$$

and

$S_{w}+1=$

$\left\{E_{s i}\left(T_{b t m}\right)+x\left(E_{s i}\left(T_{t o p}\right)-E_{s i}\left(T_{b t m}\right)\right) / d\right\} / E_{s w}(T)$,

where $d$ is the distance between top and bottom plates, and $E_{s i}$ and $E_{s w}$ are saturation vapor pressure for ice and water, respectively. These temperature and vapor pressure profiles produce a gentle maximum of saturation ratio just below the center plane $(x=d / 2)$, and, since a thin sample layer is placed at around the center, $S_{w}$ takes a value close

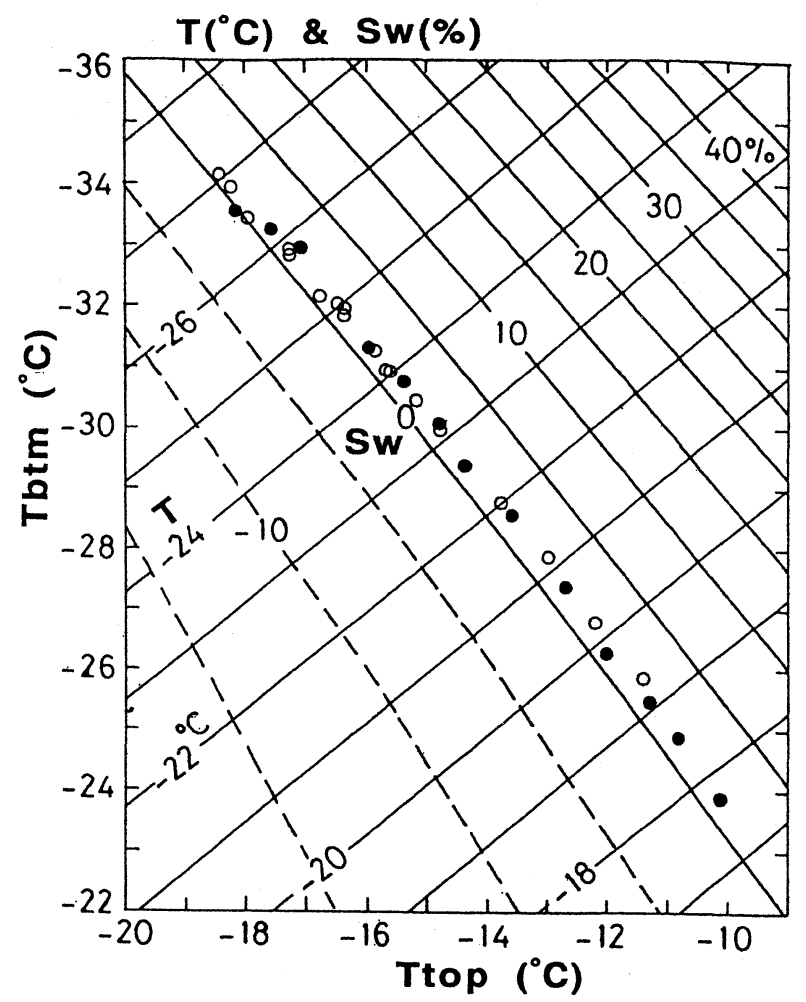

Fig. 1. The threshold condition of droplet formation achieved in the chamber by controlling the bottom plate temperature $\left(T_{b t m},{ }^{\circ} \mathrm{C}\right)$ and the top plate temperature $\left(T_{t o p},{ }^{\circ} \mathrm{C}\right) . S_{w}(\%)$ describes the supersaturations with respect to water, and closed and open circles represent conditions at the first appearance of clouds by increasing $S_{w}$ when the bottom plate is coated lightly with ethylene glycol and without it, respectively. 
to the maximum. It is clear that higher supersaturations in the chamber are caused by larger temperature differences between the bottom and top plates. To achieve higher $S_{w}$ up to about $10 \%$, we added the thermoelectric modules for cooling to the bottom plate, although the additional modules were limited to five by the original chamber frame design so that $S_{w}$ up to $10 \%$ under the chamber temperature lower than about $-24^{\circ} \mathrm{C}$ was not always achieved.

To avoid the spurious ice nucleus count problem arising from ice crystal protrusion on the bottom surface of the chamber, the ice surface was coated with a thin layer of ethylene glycol. According to thermodynamics of phase equilibria, ethylene glycol is expected to reach an equilibrium with ice by dissolving it and forming a solution. This solution should give a water vapor pressure the same as that of ice under coexistence. Conditions for the first appearance of clouds by increasing $S_{w}$ under the bottom plate coated with and without ethylene glycol are represented by closed and open circles in Fig. 1, respectively. It was confirmed from the figure that water saturation $\left(S_{w}=0 \%\right)$ could be achieved under the identical condition of the chamber without troublesome ice protrusion on the bottom plate.

In addition, blank tests with aerosol-free air were carried out to verify suppression of the spurious ice crystal generation by ethylene glycol coating. The corresponding concentration of ice crystals for the blank tests using the air sample processed by an absolute filter with and without ethylene glycol under the condition of $-20^{\circ} \mathrm{C}$ and $S_{w} 5 \%$ were about 0.5 and more than several per liter, on average, respectively. Since the typical natural ice nucleus concentration under the same condition was about several per liter, corresponding to the background counts without ethylene glycol, the effect of ethylene glycol coating to suppress a false count was remarkable. For the calculation of ice nucleus concentration, the nucleus count was corrected by subtracting the background count with ethylene glycol for each measurement.

\subsection{Procedures}

Measurements were performed with outdoor air at the northwest corner of the eighth floor of the Browning Building, University of Utah. To obtain supersaturation dependency of natural ice nuclei in the same air sample without significant deterioration, it was necessary to carry out the measurement in one day: The air sample was first stored in an antistatic bag with a capacity of $1.5 \mathrm{~m}^{3}$, and then about 20 liters of the sample air was drawn from the bag into the chamber through a $1.4-\mathrm{m}$ long, $10-\mathrm{mm}$ inner diameter copper pipe.

Preliminary tests showed that ice nucleus concentration in the bag decreased with time. Number con- centration, $N$, at time $t$ (hour) was approximately estimated as,

$$
N=N_{o} \exp (-0.2 t),
$$

where $N_{o}$ is the number concentration at $t=0$. This form corresponds to that of the number concentration being decreased due to sedimentation in an enclosed vessel (Green and Lane, 1964). With Eq. (3) the measurements were corrected according to the period the sample was held in the bag.

\section{Results}

\subsection{Daily variation}

Figure 2 shows daily values of ice nucleus concentration under the condition of $-20^{\circ} \mathrm{C}$ and $S_{w} 5 \%$ and of mass concentration of particulate matter in the air. Data on the particulate matter was measured at the site of the Utah Bureau of Air Quality, which is located about $4 \mathrm{~km}$ west of the University of Utah. The method of the measurement was in accordance with the code of federal regulations (National Archives and Records Administration, 1989). An air sampler draws ambient air, and particulate matter with an aerodynamic diameter less than or equal to a nominal $10 \mu \mathrm{m}$ is collected on a filter. The filter is weighed before and after use, and the mass concentration is computed as the total mass of collected particles divided by the volume of sampled air.

There is a positive correlation between the ice nucleus concentration and the mass concentration of the particulate matter in Fig. 2. It is noted that

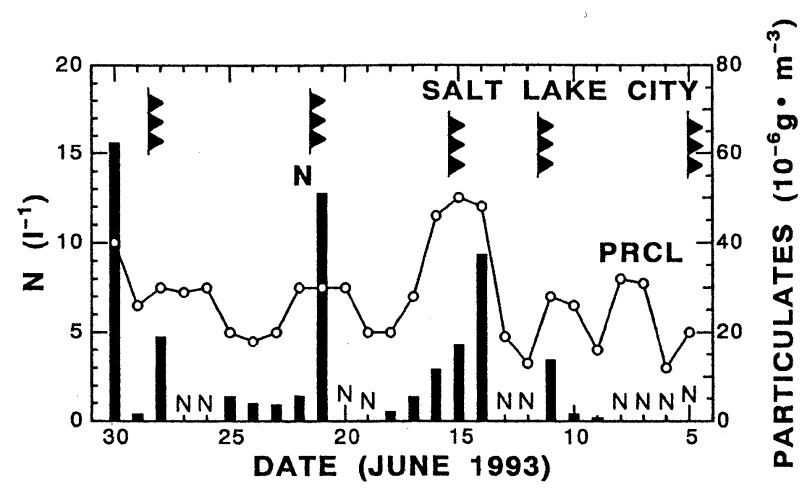

Fig. 2. Daily variation of the number concentration $\left(N, l^{-1}\right)$ of ice nuclei at $-20^{\circ} \mathrm{C}, S_{w} 5 \%$ and of the mass concentration of particulate matter (PRCL) in the air measured during June 1993. Lines with barbs denote passages of a cold front, and the smaller letter, $N$, indicates no data for the number concentration of ice nuclei. The mass concentration of the particulate matter was measured at the site of the Utah Bureau of Air Quality. 

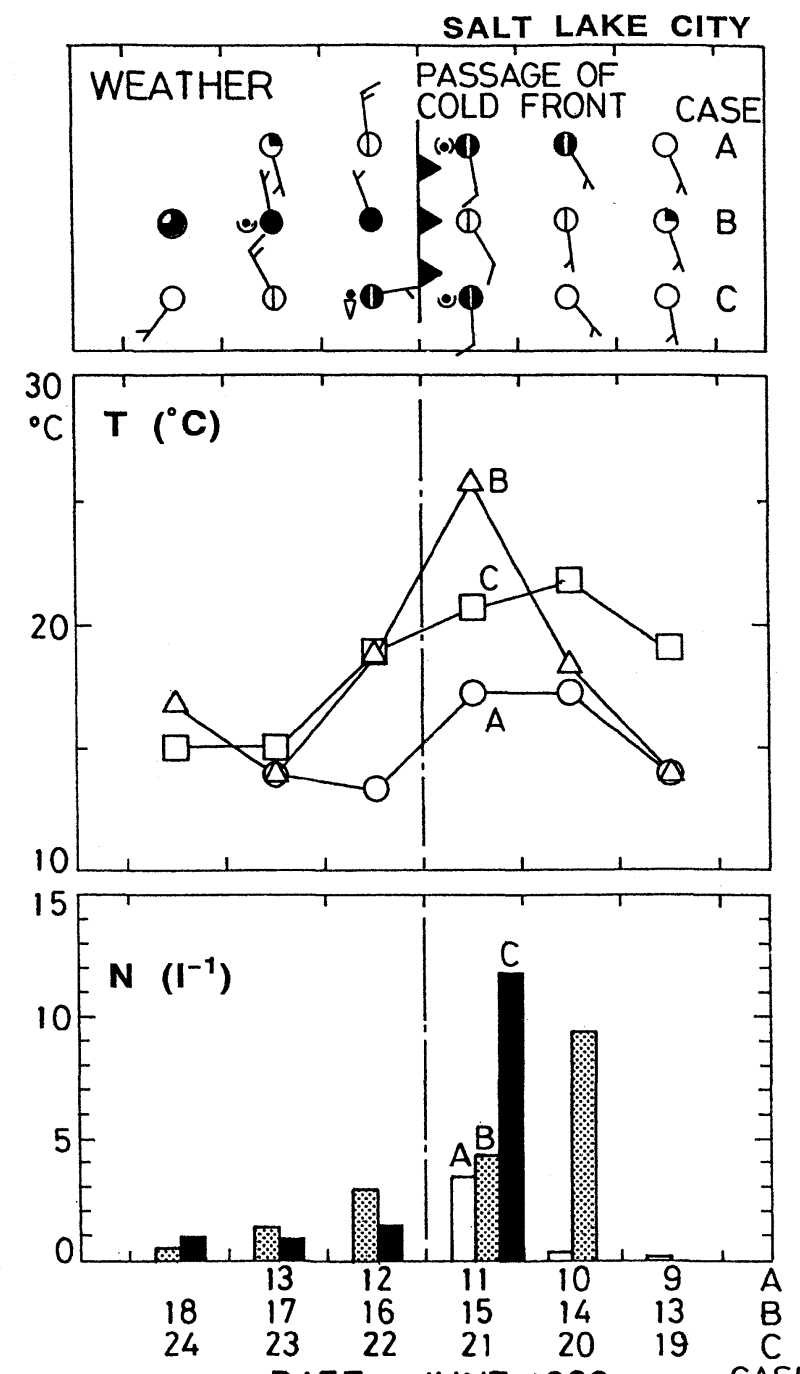

DATE, JUNE 1993

Fig. 3. Variation of weather and wind (top), air temperature $\left(T,{ }^{\circ} \mathrm{C}\right)$ (middle), and number concentration $\left(N, l^{-1}\right)$ of ice nuclei under the condition of $-20^{\circ} \mathrm{C}$ and $S_{w} 5 \%$ (bottom) for three cold frontal passages (A, B and C).

both of them tend to be higher at or just before the passage of a cold front and to fall behind it.

To obtain the general trend of ice nucleus concentration and meteorological elements during the cold front passage, their variations were superimposed for three cases in Fig. 3. Southerly winds with higher temperature and higher ice nucleus concentration (about $10 l^{-1}$ ) were observed before cold front passages, while northerly winds with lower temperature and lower concentration (about $1 l^{-1}$ ) dominated after the passages.

\subsection{Supersaturation dependence}

Figure 4 shows supersaturation dependence of ice nucleus concentration measured at $-20^{\circ} \mathrm{C}$ for 8 observation days. It is noted that the concentration tends to increase with supersaturation, although it varies largely from day to day.

In order to obtain a supersaturation dependence in daily variation of ice nucleus concentration, the ratio of the concentration $(N)$ to that at water saturation $\left(N_{o}\right)$ was calculated. Figure 5 shows average supersaturation dependence of the number concentration for -20 and $-24^{\circ} \mathrm{C}$. There is a clear increase in the ratio, $N / N_{o}$, with $S_{w}$. On average, a $S_{w}$ increase of 5 and $10 \%$ from the water saturation resulted in an $N / N_{o}$ increase by as much as a factor of two or more, respectively. In addition, the gradient with respect to $S_{w}$ increased above the water saturation for both -20 and $-24^{\circ} \mathrm{C}$. These results suggest that the deposition nuclei below water saturation and both deposition and condensation-freezing nuclei above water saturation were activated.

\section{Discussions}

In the previous section, the daily variation and the supersaturation dependency of ice nucleus concentration were analysed. In order to provide some insight for the ice nucleus measurements under high supersaturation, we shall compare them with other measurements below.

\subsection{Daily variațion}

There are various works showing temporal variations in the ice nucleus concentration observed by two different methods: the mixing cold chamber and the filter method. With the mixing cold chamber, which basically gives the condition at $S_{w}=0$ (at the water saturation), Schaefer (1954) reported a seasonal change of ice nucleus concentration at the summit of Mt. Washington in the northeastern part of the United States. Isono et al. (1956 and 1966) observed the variation of ice nucleus concentration in Japan. Bigg and Hopwood (1963) and Kikuchi (1971) measured the fluctuation of ice nucleus concentration in the Antarctic. With the filter method, Al-Naimi and Saunders (1985a) and Bowdle et al. (1985) observed daily values of ice nucleus concentrations over the United Kingdom and the High Plains of the United States, respectively. However, as mentioned above, these methods have some problems; the volume effect due to growing ice crystals, the substrate effect and the effect of hygroscopic particles on filters in the filter method and the transient supersaturations during the sample air introduction in the mixing chamber (Tomlinson and Fukuta, 1985; Al-Naimi and Sounders, 1985b; Vali, 1985). Therefore, it is necessary to consider the time variation of ice nucleus concentration observed with the above methods only as qualitative. The measurement of ice nucleus concentration with the present continuous flow diffusion chamber avoids these shortcomings. 


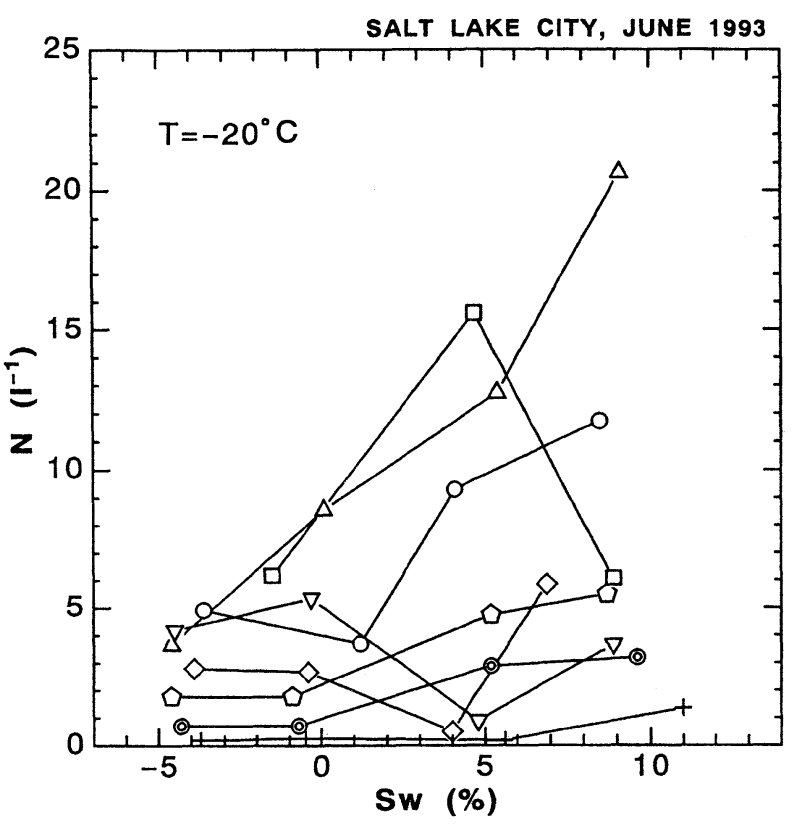

Fig. 4. The number concentration $\left(N, l^{-1}\right)$ of ice nuclei at $-20^{\circ} \mathrm{C}$ plotted as a function of water supersaturation $\left(S_{w}, \%\right)$. Each mark represents a different observation day in June 1993.

It was shown in Section 3.1 that the number concentration of ice nuclei under supersaturation and the mass concentration of particulate matter in the air tended to be higher at or just before the passage of a cold front and to fall behind it. This tendency towards ice nucleus concentration and particulate matter during the frontal passage is in agreement with the results obtained with the filter method (Al-Naimi and Saunders, 1985a; Bowdle et al., 1985). Al-Naimi and Saunders (1985a) attribute this decrease after the cold frontal passage to the precipitation scavenging and the replacement of the polluted air by the cleaner air behind the fronts. The present measurement of ice nuclei clearly shows the influence of meteorological conditions on ice nucleus concentration in the air.

\subsection{Supersaturation dependence}

Ice nucleus activity is known to be highly dependent on both temperature and supersaturation (Schaller and Fukuta, 1979). For measurement of natural ice nuclei above water saturation, there have been various works with the filter method (Huffman, 1973; Langer and Rogers, 1975; Zamurs and Jiusto, 1982; Stein and Georgii, 1982 and 1985; Berezinskiy and Stepanov, 1986; Rosinski et al., 1987; Rosinski and Morgan, 1988 and 1991). However, the filter method frequently used has a number of inherent problems, as mentioned above.

To avoid such problems, continuous flow diffusion chambers are advantageous. Hussain and Saunders

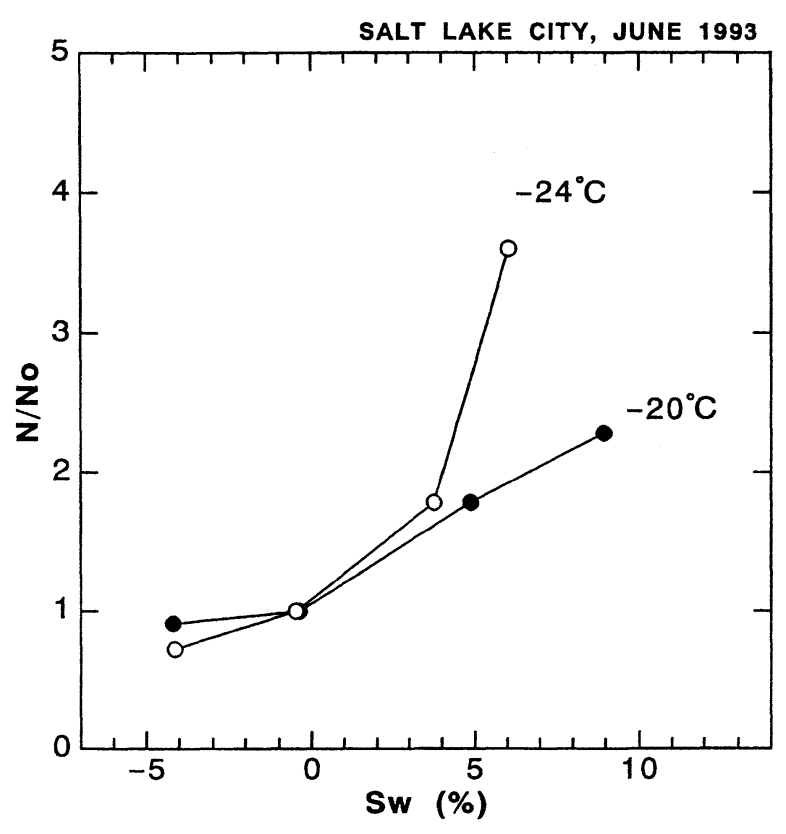

Fig. 5. Average supersaturation dependence of ice nucleus number concentration $\left(N, l^{-1}\right)$ normalized by that at water saturation $\left(N_{o}, l^{-1}\right)$. Closed and open circles are for -20 and $-24^{\circ} \mathrm{C}$, respectively.

(1984) carried out their measurement under the condition of $-16^{\circ} \mathrm{C}$ and $S_{w}<2 \%$. Al-Naimi and Saunders (1985b) measured ice nucleus concentrations at $-12,-16$ and $-20^{\circ} \mathrm{C}$ for the condition up to $S_{w} 1 \%$. Rogers (1993) made measurements of natural ice nuclei in winter continental air masses over the range of temperatures from -7 to $-20^{\circ} \mathrm{C}$ and that of $S_{w}$ up to $5 \%$. These studies show some evidence of two different ice nucleation mechanisms operating: deposition nucleation for $S_{w}<0 \%$ and condensation-freezing nucleation for $S_{w}>0 \%$. However, ice nucleus measurement under even higher $S_{w}$ up to $10 \%$ is needed to check the hypothesis with respect to high ice particle concentration in some clouds (Rangno and Hobbs, 1991; Hobbs, 1993).

The present study extended the ice nucleus measurement into the range of temperature from -20 to $-24^{\circ} \mathrm{C}$ and of $S_{w}$ up to $10 \%$. Since the measurements showed daily variation of ice nucleus concentration, supersaturation dependence of the ratio $N / N_{o}$ was estimated. It was found that the ratio increased with $S_{w}$ and the gradient increased above water saturation. This is attributed to characteristics of nucleation modes: deposition nucleation below and above water saturation, and condensationfreezing nucleation above water saturation. The results of the present study agree with those of the above-mentioned studies with different continuous flow chambers, in spite of the additional differences 
in the location, time, temperature and supersaturation ranges of the measurements. The present study suggests the need for more detailed ice nucleus measurements under high supersaturation at a wide range of temperatures.

It is also noted that the supersaturation dependence in Fig. 4 is scattered day by day. The daily variation of supersaturation dependence is considered to be associated with the number, composition and characteristics of ice nuclei. Further detailed measurements of ice nuclei addressing these aspects will be required in the future.

\section{Conclusions}

It is important for precipitation formation in middle and high latitudes and for radiative properties of cold clouds to know the concentration of natural ice nuclei in clouds. To understand ice nucleation under high supersaturation in some clouds, measurements of natural ice nucleus activity as a function of $S_{w}$ up to $10 \%$ from -20 to $-24^{\circ} \mathrm{C}$ were carried out with a horizontal gradient, continuous flow, ice thermal diffusion chamber solving the spurious ice crystal count problem by the ice protrusion on the bottom plate by the addition of a small amount of ethylene glycol. The measurements were made in continental air masses in early summer of 1993 at Salt Lake City, Utah. The main results are summarized as follows:

(1) Average increases of the concentration of ice nuclei relative to the increases of $S_{w}$ for 5 and $10 \%$ were as much as a factor of two or more, respectively.

(2) The ice nucleus concentration under the condition of $-20^{\circ} \mathrm{C}$ and $S_{w} 5 \%$ varied from about $10 l^{-1}$ in warm air to about $1 l^{-1}$ in cold air, respectively, before and after the passage of a cold front on the synoptic scale.

(3) The increase of the concentration of ice nuclei and other particulates in the warm air mass before the front arrives is inferred to be due to the air mass instability that kicks the particulates up from and above the ground.

\section{Acknowledgements}

We thank the Utah Bureau of Air Quality of the Utah State Department of Health for providing data on particulate matter, Dr. E.M. Tomlinson of North American Weather Consultants, for his suggestion on chamber operation, and Mr. B.E. McDonald of the University of Utah, for his assistance with meteorological information. This work was done while one of us (H. M.) was visiting the University of Utah under NSF grant ATM-9112888 and the Part Guarantee Program of the Science and Technology Agency, Japan.

\section{References}

Al-Naimi, R. and C.P.R. Saunders, 1985a: Ice nucleus measurements: effect of site location and weather. Tellus, 37B, 296-303.

Al-Naimi, R. and C.P.R. Saunders, 1985b: Measurements of natural deposition and condensationfreezing ice nuclei with a continuous flow chamber. Atmos. Environ., 19, 1871-1882.

Bigg, E.K. and S.C. Hopwood, 1963: Ice nuclei in the Antarctic. J. Atmos. Sci., 20, 185-188.

Bowdle, D.A., P.V. Hobbs and L.F. Radke, 1985: Particles in the lower troposphere over the High Plains of the United States. part 3: Ice nuclei. J. Climate Appl. Meteor., 24, 1370-1376.

Berezinskiy, N.A. and G.V. Stepanov, 1986: Dependence of the concentration of natural ice-forming nuclei of different size on the temperature and supersaturation. Izv. Atmos. Ocean. Phys., 22, 722-727.

Brough, R.C., D.L. Jones and D.J. Stevens, 1987: Utah's Comprehensive Weather Almanac. Publishing Press, 517pp.

DeMott, P.J., D.C. Rogers and L.W. Grant, 1992: Concerning primary ice nuclei concentrations and water supersaturations in the atmosphere. 11th ICCP, Montreal, 1992, Proceedings, Vol. 1, 284-287.

Fukuta, N., 1993: Water supersaturation in convective clouds. Atmos. Res., 30, 105-126.

Green, H.L. and W.R. Lane, 1964: Particulate Clouds: Dust, Smokes and Mists. Spon London, 471pp.

Griggs, D.J. and T.W. Choularton, 1986: A laboratory study of secondary ice particle production by the fragmentation of rime and vapour-grown ice crystals. Quart. J. Roy. Meteor. Soc., 112, 149-163.

Hall, W.D., 1980: A detailed microphysical model within a two-dimensional dynamic framework.: Model description and preliminary results. J. Atmos. Sci., 37, 2486-2507.

Hallett, J. and S.C. Mossop, 1974: Production of secondary ice particles during the riming process. $\mathrm{Na}$ ture, 249, 26-28.

Hobbs, P.V., 1969: Ice multiplication in clouds. J. Atmos. Sci., 26, 315-318.

Hobbs, P.V. and R.J. Farber, 1972: Fragmentation of ice particles in clouds. J. Rech. Atmos., 6, 245-258.

Hobbs, P.V., 1974: Ice Physics. Oxford Univ. Press, 837pp.

Hobbs, P.V. and A.L. Rangno, 1985: Ice particle concentrations in clouds. J. Atmos. Sci., 42, 2523-2549.

Hobbs, P.V. and A.L. Rangno, 1990: Rapid development of high ice particle concentrations in small polar maritime cumuliform clouds. J. Atmos. Sci., 47, 2710-2722.

Hobbs, P.V., 1993: The Eleventh International Conference on Clouds and Precipitation. Bull. Amer. Meteor. Soc., 74, 835-844.

Huffman, P.J., 1973: Supersaturation of AgI and natural ice nuclei. J. Appl. Meteor., 12, 1080-1082.

Hussain, K. and C.P.R. Saunders, 1984: Ice nucleus measurement with a continuous flow chamber. Quart J. Roy. Meteor. Soc., 110, 75-84.

Isono, K., M. Komabayashi and A. Ono, 1959: The nature and the origin of ice nuclei in the atmosphere. 
J. Meteor. Soc. Japan, 37, 211-233.

Isono, K., M. Komabayashi, T. Takahashi and T. Tanaka, 1966: A physical study of solid precipitation from convective clouds over the sea: part 2 . - Relation between ice nucleus concentration and precipitation -. J. Meteor. Soc. Japan, 44, 218 226.

Kikuchi, K., 1971: Observation of concentration of ice nuclei at Syowa station, Antarctica. J. Meteor. Soc. Japan, 49, 20-31.

Langer, G. and J. Rogers, 1975: An experimental study of the detection of ice nuclei on membrane filters and other substrata. J. Appl. Meteor., 14, 560-570.

Mossop, S.C., 1985: The origin and concentration of ice crystals in clouds. Bull. Amer. Meteor. Soc., 66, 264-273.

Mossop, S.C. and J. Hallett, 1974: Ice crystal concentration in cumulus clouds: Influence of the droplet spectrum. Science, 186, 632-634.

National Archives and Records Administration, 1989: Reference method for the determination of particulate matter as PM10 in the Atmosphere. Code of federal regulations. Protection of environment. 40, part 50, App. J.

Pruppacher, H.R. and J.D. Klett, 1980: Microphysics of Cloud and Precipitation. D. Reidel Publ. Co., Boston, 714pp.

Rangno, A.L. and P.V. Hobbs, 1991: Ice particle and precipitation development in small polar maritime cumuliform clouds. Quart. J. Roy. Meteor. Soc., 117, 207-241.

Rogers, D.C., 1993: Measurements of natural ice nuclei with a continuous flow diffusion chamber. Atmos. Res., 29, 209-228.

Rosinski, J., P.L. Haagenson, C.T. Nagamoto and F. Parungo,1987: Nature of ice-forming nuclei in marine air masses. J. Aerosol Sci., 18, 291-309.

Rosinski, J. and G.M. Morgan, 1988: Ice-forming nuclei in Transvaal, Republic of South Africa. J. Aerosol
Sci., 19, 531-538.

Rosinski, J. and G.M. Morgan, 1991: Cloud condensation nuclei as a source of ice-forming nuclei in clouds. J. Aerosol Sci., 22, 123-133.

Schaefer, V.J., 1954: The concentration of ice nuclei in air passing the summit of Mt. Washington. Bull. Amer. Meteor. Soc., 35, 310-314.

Schaller, R.C. and N. Fukuta, 1979: Ice nucleation by aerosol particles: Experimental studies using a wedge-shaped ice thermal diffusion chamber. J. Atmos. Sci., 36, 1788-1802.

Stein, D. and H.W. Georgii, 1982: Investigation on the saturation spectra of ice nuclei. Idojaras, 86, 124130.

Stein, D. and H.W. Georgii, 1985: Supersaturation spectra of ice nuclei at different locations in Europe and over the North-Atlantic ocean. J. Rech. Atmos., 19, 179-184.

Stevens, D.J., R.C. Brough, R.D. Griffin, and E.A. Richardson, 1983: Utah Weather Guide. Department of Geography, Brigham Young University, $46 \mathrm{pp}$.

Takahashi, T., 1993: High ice crystal production in winter cumuli over the Japan Sea. Geophys. Res. Letter, 20, 451-454.

Tomlinson, E.M. and N. Fukuta, 1985: A new horizontal gradient, continuous flow, ice thermal diffusion chamber. J. Atmos. Ocean. Tech., 2, 448-467.

Vali, G., 1985: Atmospheric ice nucleation-a review. $J$. Rech. Atmos., 19, 105-115.

Vardiman, L., 1978: The generation of secondary ice particles in clouds by crystal-crystal collision. J. Atmos. Sci., 35, 2168-2180.

Young, K.C., 1974: The role of contact nucleation in ice phase initiation in clouds. J. Atmos. Sci., 31, 768-776.

Zamurs, J. and J.E. Jiusto, 1982: An examination of ice nucleus concentrations in eastern New York State. $J$. Appl. Meteor., 21, 431-436.

\title{
高過飽和度における自然水晶核の測定
}

\author{
水野 量 \\ (気象研究所) \\ 福田矩彦 \\ (ユ夕大学)
}

\footnotetext{
雲内の高過飽和度における氷晶発生を理解するため、連続流拡散型水晶発生装置を用いて $-20 \sim-24^{\circ} \mathrm{C}$ について過飽和度 $10 \%$ までの自然水晶核の測定を行った。装置下面の水面に少量のエチレングリコールを 塗布して、装置内で自生する氷晶の影響を抑えた。測定は、1993年初夏にユタ州ソルトレークシティにお いて大陸性気団内で行われた。
} 
測定の結果、 $-20^{\circ} \mathrm{C}$ 、過飽和度 $5 \%$ の条件における水晶核数濃度は、日々大きく変動した。寒冷前線通 過前の暖気内で 10 個/1、寒冷前線通過後の寒気内で 1 個/1 であった。また、各々の測定值の過飽和度 $0 \% に お け る$ 測定值に対する比を求めて、この日々変動をした氷晶核数濃度の中から過飽和度依存性を調 べた。その結果、過飽和度 $5 \%$ と $10 \%$ における氷晶核数濃度は、過飽和度 $0 \%$ における值のそれぞれ 2 倍 と数倍に増加することが分かった。 